Please do not remove this page

RMIT

UNIVERSITY

\title{
The Evolution of the Open Textbook Initiative
}

Ponte, Frank; Lennox, Anne; Hurley, Jennifer

https://researchrepository.rmit.edu.au/esploro/outputs/9922007196601341/filesAndLinks?institution=61RMIT_INST\&index=null

Ponte, F., Lennox, A., \& Hurley, J. (2021). The Evolution of the Open Textbook Initiative. Journal of the Australian Library and Information Association, 70(2), 194-212.

https://doi.org/10.1080/24750158.2021.1883819

Document Version: Accepted Manuscript

Published Version: https://doi.org/10.1080/24750158.2021.1883819

Repository homepage: https://researchrepository.rmit.edu.au

(C) 2021 Frank Ponte, Anne Lennox and Jennifer Hurley.

Downloaded On 2023/04/26 19:34:45 +1000 


\section{The evolution of the Open Textbook Initiative}

In 2018, RMIT University Library was awarded \$5,000 fellowship from Libraries of the Australasian Network (LATN) to investigate opportunities in open educational resources (OER). The reasons behind the application were to advocate and increase the use of OER, increase knowledge and expertise in open licensing, and leverage support, advice and appropriate infrastructure from LATN members.

The associated benefits to LATN would include the establishment of an OER community of practice and the development of shared tools and resources to facilitate the uptake of open educational resources at home institutions. This is the story of how the Open Textbook Initiative evolved and how a deliberate campaign to increase awareness and adoption of OER was created. Activities included delivering OER awareness sessions, aligning OER textbooks with selected subject areas, delivering an open textbook forum, with local and international speakers, and creating a savings bank for self-reported OER adoptions. The OER textbook hero program was developed to highlight the teaching challenges faced by academic staff and explore their responses. As a result of this activity, there has been greater visibility of OER and the discussion has evolved from textbook affordability to open educational practices.

Keywords: open educational resources; oer; open textbooks; oep; open educational practices; open pedagogy 


\section{Introduction}

In 2017, RMIT University saw a unique opportunity to create a consortium of librarians to facilitate awareness raising and uptake of open educational resources (OER). It was apparent that the acceptance and use of open educational resources in the Australian context was a growing phenomenon, but limitations existed that hindered the uptake, such as institutional resistance to allow access to content, copyright and intellectual property matters (Bull et al., 2011). In contrast, a worldwide movement in the adoption and use of open textbooks via several initiatives was generating clear momentum leading to strategic policy development (Bossu \& Stagg, 2018).

In the RMIT context, librarians and academic staff explored and engaged in the use of open educational resources, but the development of incentives to adopt open textbooks were slow to non-existent. RMIT University Library investigated open educational resources in 2012 in support of the use of fine art images in undergraduate fine art programs, advising academic and teaching staff to shift their practice in the educational use of fine art images from copyright protected images to Creative Commons images. This work morphed to exploring and facilitating the adoption of OER as an extension of the Library's existing roles in digital curation, management of collections, and promotion of information resources. The Library then began managing OER collections, which were openly accessible through RMIT's Library catalogue - Library Search.

Across Australian universities a gap in expertise existed in supporting awareness raising and information sharing in the development, storage and use of open educational resources (Bossu, Brown, \& Bull, 2012). In 2017, RMIT submitted a proposal to the Libraries of the Australia Technology Network (LATN), seeking funding to investigate OER developments in leading countries such as Canada to 
explore models of support for the establishment of a consortium of librarians drawn from LATN members.

\section{OER textbook adoption in Australian Universities}

The Open Educational Resources movement began to take shape in 2002 (Bliss \& Smith, 2017). In 1997, the California State University created MERLOT (Multimedia Educational Resources for Learning and Online Teaching) to provide free access to online learning materials. Resources ranged from full courses and textbooks to test banks and software (MERLOT, n.d.). In parallel with the development of MERLOT, David Wiley, a professor at Utah State University, proposed a new license that made it easier for others to legally use teaching resources for free (Matt, 2003). Creative Commons was founded in 2001 and in December 2002, a set of machine-readable licenses were released that allowed the user to legally revise, reuse, retain, redistribute, and remix content (Creative Commons, 2011). The licenses overlaid the author's original copyright and established rules by which users could legally take a resource and use it according to the badged license parameters without fear of breaching copyright.

One type of open educational resource that has been gaining prominence over the last five years is the open textbook, largely due to the exorbitant prices of commercial textbooks across the world. In the United States of America, data from the Bureau of Labor Statistics suggests that the price of textbooks has risen four times as fast as inflation over the past forty years, which means that the cost of textbooks has increased by 1,041 percent (Vitez, 2018).

Australia has also identified textbooks and study supplies affordability as a major equity issue for students. In the latest report by Universities Australia, 58.2\% of undergraduates reported high financial stress in terms of their work/study balance. This 
percentage increases for indigenous, regional, and low socio-economic status students (Universities Australia, 2018). As a result, students defer their studies, reduce their course load, and do not purchase essential study items such as textbooks, all serving to perpetuate further inequalities and hardship on their lives (Universities Australia, 2018). The excerpt below provides a clear example of how student lives are precariously balanced between living and studying:

(UG domestic full-time student) "It is really hard needing to live off $\$ 1,000$ a fortnight, due to being unable to gain paid employment as a restriction from the government as I am a full-time carer for my Mum (can only be away for 25 hours, and full-time uni, including travel uses this time), so things like pensioner discounts, or payment plans in regards to things like textbooks would be extremely useful, as it takes roughly 8 weeks of keeping money aside to be able to purchase needed books" (Universities Australia, 2018).

When discussing affordability, offering open textbook alternatives can equalise the student experience and remedy the cost issue. There are numerous other reasons why an open textbook is a better choice and can offer far more benefits to the student and the educator.

For the student, they are provided with a myriad of platforms to access their textbook, they can share it with their friends, post links to the resource without fear of copyright breaches and have perpetual and immediate access. For the educator, open texts provide greater flexibility to merge open content with course content, the ability to customise and remix material to suit cohorts, circumvent restrictive copyright and digital rights management issues, and co-create with students to produce new or adapted works. Additionally, librarians and educators forge closer ties and can establish rewards and recognition programs based on collaborative relationships (SPARC, 2017; Braddlee \& VanScoy, 2019). 
Bossu, Bull and Bown (2012) define the OER movement in Australia as emergent. They discuss pockets of OER interest and activity at various higher education institutions with little co-ordination. An attempt to bridge the gap was the development of the OpenEdOz project. This project aimed to focus on the student voice in understanding technology based on open educational practice, enhance student learning outcomes, develop case studies that captured university practice, and importantly, deliver a national policy roadmap that aimed to foster the take-up of OER and open courses (Bossu et al. 2016). The findings of this report uncovered three challenges in the implementation of OER and reinforce the need to address the efficacy of OER in the Australian context. The first related to raising student literacy of open education and creating repositories of open content for re-use. The second was raising teacher awareness of the adoption and use of OER. The third related to the provision of university infrastructure to support easy sharing and finding of OER resources (Office for Learning and Teaching, 2016).

To address the challenge of providing university infrastructure to support easy sharing and finding of OER resources, a few Australia universities have launched open textbook platforms. They are the University of Southern Queensland, Charles Darwin University and Queensland University of Technology. These universities are cognizant of the need to reduce the financial burden for students and the ability for academic staff to have flexibility to contextualize content for their student cohorts. The process of OER textbook creation also affords opportunities for authors to explore authentic, collaborative assessment practices. (University of Southern Queensland, n.d.)

RMIT Librarians address the challenge of teacher awareness and student OER literacy by using their outreach skills to advocate and promote OER through the maintenance of curated lists via subject guides. They also use their metadata, indexing, 
and classification skills to enhance access to OER textbooks by harvesting MARC records to include in the Library catalogue. In 2018, Library staff were invited to the launch of the College of Science, Engineering and Health Blended Learning Pilot program. This program engaged academic staff through a series of workshops and discussions where open textbooks, videos, simulations, and teaching resources were highlighted and ultimately utilised in online course shells. In one course the use of an OER textbook saved the student cohort $\$ 34,862$ in one semester, promoting equality of opportunity for all learners. An additional benefit noted for students was the portability of digital resources and anytime access to learning which increased their engagement outside the classroom (Rekhari, Curran, Paul, Porcaro, 2020).

Studies that review the impact of OER textbooks largely emerge from the United States and Canada. In a study conducted by the University of Georgia, it was identified that affordability of education delays student attendance at college and even halts their enrolment altogether. Those that enrol late or make the financial decision not to purchase the textbook will inevitably begin their course with constraints that negatively affects their grades and performance (Colvard et al., 2018). The study at the University of Georgia compared the final grades of students where a commercial textbook was switched with an OER textbook. By comparing the before and after grades it was found that switching to an OER textbook increased the number of A and A- grades. In addition, the number of students that withdrew from the course, or, were awarded D and F grades fell by $2.68 \%$. This percentage was higher for students from ethnically diverse and lower socio-economic backgrounds (Colvard et al., 2018). The Textbook Affordability Survey (Library Journal, 2019) conducted in 2019 reaffirms the notion that students who cannot afford textbooks and other materials are more likely to underperform or fail to graduate having a negative effect on the students' ability to 
succeed. RMIT Library works actively with academic staff to offer options such as the adoption of an OER textbook and the creation of online reading lists to minimise underperformance.

RMIT Library has a commitment to uphold the principles of equity and inclusion by ensuring resources are affordable and accessible to our cohorts. Commercial models of textbook access complicate the role of the Library by imposing exorbitant costs and copyright restrictions. Therefore, exploiting the available opportunities afforded by the open textbook movement can ensure that alternatives are genuinely considered.

A subsequent grant application offered by LATN was submitted to explore OER in more detail. It will be the aim of this paper to address the state of OER textbook adoption in Australia in the context of the successful LATN grant and what RMIT University has attempted to deliver.

\section{Background}

ATN (Australian Technology Network) brings together four 'innovative and enterprising Universities' in Australia. They are RMIT University, University of South Australia, University of Technology Sydney and Curtin University (Australian Technology Network, n.d., para 1). Previous participants included Auckland University of Technology and Queensland University of Technology. A Library interest group emerged from the institutional participants whose membership consisted of Associate Library Directors and University Librarians and are identified as LATN. This group meets regularly via video conference and arranges annual workshops at member institutions to address Library higher educational challenges. The LATN group also offer an annual fellowship of $\$ 5000$ for Library staff at member institutions to research 
a topic of interest aligning with LATN priorities.

RMIT University Library was one of the successful applicants in 2017 and awarded $\$ 5,000$ to investigate opportunities in open educational resources. The investigation was focused on leveraging the work of BCcampus in the development of a consortium of Libraries with the primary purpose of advocating and promoting the benefits of open for a successful learning experience. The focus of the LATN consortium was intended to build a solid understanding of the open educational landscape to support broader implementation of OER in LATN member institutions.

The following outcomes were outlined in the grant application:

(1) Advocate and increase the use of OER within the ATN

(2) Increase knowledge and expertise in LATN member universities in OER and open licensing.

(3) Leverage support, advice and appropriate infrastructure from Creative Commons Australia to run local activities. Such as the promotion of Open Education Week that occurs annually.

The associated benefits to LATN included:

(1) The establishment of an OER community of practice in support of open educational resources within LATN member universities.

(2) The development of shared tools and resources to facilitate the uptake of OER within LATN member Universities.

(3) The establishment of a trusted collection of OER for re-use by LATN member universities. 
The funding was primarily used to travel to BCcampus. BCcampus is a well-established funding and support body in the province of British Columbia, Canada. BCcampus' primary purpose is to support the development of open educational resources by taking an active role in the creation, modification, distribution, and evaluation of open teaching, learning, and research resources, through the open textbook development project and other projects (BCcampus, n.d., Open Education Advocacy: Open Educational Resources, para 4).

Included into the travel itinerary was attendance at the Festival of Learning Conference in Vancouver, Canada and meetings with Rajiv Jhangiani, (Special Advisor to the Provost on Open Education and a Psychology Instructor at Kwantlen Polytechnic University) Brenda Smith (Open Education Librarian - Thompson Rivers University) and Lauri Aesoph (BCcampus).

\section{Learning from BCcampus}

The province of British Columbia in Canada acknowledged the importance of open educational textbooks by the commitment of a 1,000,000 Canadian dollar grant in 2012 to $\mathrm{BC}$ campus, a state funded group to provide 'teaching, learning, educational technology, and open education support to the post-secondary institutions of British Columbia' (BC campus, n.d., Our Mandate, para 1). The grant aimed to provide the means of creating equitable access to education through lowering costs of resources to students and increasing the relevance and engagement with learning and teaching materials. In addition, there was a clear mandate to produce 20 textbooks in areas in which, as a province, had skills gaps, such as tourism, technology, healthcare, and adult basic education. Each textbook produced was aligned with the most highly enrolled first and second year subject areas in British Columbia public post-secondary institutions. 
(Burgess, 2017).

In Australia, there is a critical need to emulate the Canadian experience through government supported funding. A commitment to do so would provide the impetus to establish strong underpinnings to a more equitable education. It reduces costs for all students, particularly those from low socio-economic backgrounds, and, emerging research suggests that OER driven courses have greater student success (Colvard et al., 2018). However, there is a reticence in Australia to fund such initiatives which may stem from institutional competition that generates billions of dollars of export income from international education (Bossu, Bull, \& Brown, 2012).

BCcampus employees delivered multiple presentations on OER covering issues including the quality of OER and Creative Commons licenses. The need for OER tailored to Canadian audiences was an immediate barrier for academic staff, as many of the resources emanated from textbook platforms in the United States. Another barrier to adoption for academic staff was an expectation of supporting ancillary materials. These materials included powerpoint slides, test banks and teaching notes. BCcampus supported the creation of ancillary resources by running development and collaborative sprints to provide academics greater incentive to adopt open textbooks (Burgess, 2017). An example of collaborative action was the launch of a two-day event held in 2014 and attended by over 15 psychology instructors which resulted in the creation of a reusable bank of exam questions (Jhangiani, 2014). In Australia, there is no overarching entity that is funded to deliver teaching and learning support and the creation of OER on a broad scale. For this reason, we continue to see only pockets of excellence from communities of practice, special interest groups and individuals who promote the benefits of OER. A call for a national strategic approach to open scholarship continues to remain unheeded (Barbour \& Borchert, 2020). 
A key concern for many academic staff in Australia is the quality of open textbooks. Perceptions of quality are usually shaped by the commercial textbook model and linked to a clear aesthetic and publishing style. The issue can be addressed by the acquisition of an authoring platform like Pressbooks that can manage adapted works and create original content. It also has built in workflows that allows for multiple author access, daily backups and has a simple and familiar interface with inbuilt version control. Pressbooks provides HTML, PDF, MOBI and EPUB versions of textbooks. The platform has a professional aesthetic which subsequently provides credibility to the user. (Burgess, 2017). The quality of a resource is also addressed by peer review, the 2016 National Road Map articulated that fostering peer review and collegial development of resources was a key area of national support. (OpenEdOz National Roadmap, 2016). BCcampus provides a small stipend to qualified peer reviewers to evaluate an open textbook. The payment also incentivises the reviewer to adopt the resource in their own course delivery.

BCcampus used qualitative and quantitative methods to measure success, including averaging the cost of a prescribed textbook at 100USD and calculating savings based on adoptions. Institutional culture change was evidenced by the number of OER adoptions and an increasing awareness of social justice principles where student access and learning were increasingly valued. Other measures included the number of OER working groups established within academic institutions, and policy changes that incentivised and recognised the development of OER as evidence towards promotion and tenure for academic staff (Burgess, 2017).

Students' from local institutions were also keen to get on board as they saw the benefits of advocating for OER textbooks, as demonstrated through a successful campaign using the Twitter hashtag \#textbookbrokeBC (BCFS, 2019). The learning 
from the BCcampus visit and our discussion with OER champions in Canada provided RMIT Library with a strong foundation to emulate a similar strategy in Australia. Australia's OER initiatives are nascent and fragmented and there are limited projects due to organisational passivity, usually in the form of a lack of institutional guidelines and support (Bossu, Bull, \& Brown, 2012). This notion is reinforced by a survey conducted by Bossu, Bull, \& Brown (2012) where respondents believed that a lack of government public policy in OER adoption was a major roadblock that reduced uptake and growth.

While the lack of institutional guidelines and government support hinder the growth of OER in Australia, there is still a groundswell of interest in OER textbooks. Driven by an increase in diverse student populations at University and challenges to the traditional approach to course delivery, the role of open resources becomes an interesting proposition in the context of equitable access to a university education (Partridge et al., 2016). Awareness and adoption continue to remain low in Australian universities (Bossu et al., 2015 in Partridge et al., 2016), however, this is merely the first stage in the initial engagement with OER textbooks. The aim is to engage academic staff with open educational practices (OEP). OEP is simply defined as the engagement of students as creators of information rather than consumers. It is a form of experiential learning in which students are empowered to demonstrate their ability through the act of creation. OEP aims to create the environment where OER are used and produced with highly engaged learning outcomes (Partridge et al., 2016) (BCcampus, n.d. What is Open Pedagogy, para 3).

To engage in the development of OER in Australia and emulate the success in British Columbia, there are three main areas of concern that need to be addressed to overcome resistance towards OER textbooks. 
Firstly, low awareness and scepticism associated with their quality is a common first encounter with academic staff. The general assumption from staff is if they are free they are flawed questioning their quality and authority. This perception is changing with the proliferation of quality peer reviewed OER textbooks from OpenStax, BCcampus and Open Textbook Network. These platforms pride themselves on delivering authoritative works from notable authors that have undergone rigorous peer review. A study from North America also concludes that 50 percent of students classed OER textbooks to be as good as traditional texts and 35 percent indicated that they were superior. (Bliss, TJ, Hilton III, John, Wiley, David, \& Thanos, Kim, 2013).

The second reason is associated with reward and recognition. Asking academic staff to consider authoring an open textbook is often associated with career aspirations. In higher education, reward and recognition is attributed to a traditional model of research publishing. Most see open publishing as having little value and don't regard it as fundamental to their career aspirations. (Browne, T., Holding, R., Howell, A., Rodway-Dyer. S. 2010). The challenge for librarians is to convey credibility associated with authoring open textbooks and the impact that an open publication can have on access and student learning. It is also important to point out how universities are now recognizing open authorship as a pathway to promotion and tenure. (University of British Columbia, (n.d.))

The third reason relates to inertia or investment of time and effort. This is by far the most difficult as it requires the academic to prioritise change. A time poor academic staff member will balk at adapting an open resource for reasons that relate to time, effort and money. Adaptation requires the review of a new resource, the use or development of ancillary resources to support the text, and customisation of the OER to ensure there are relatable case studies and local content for sustained student 
engagement (Walz, 2017). These reasons will often impede a willing staff member to investigate the benefits of an OER textbook. Hence, a sound infrastructure supporting review, customisation, and the creation of ancillary resources are critical requirements to have in place from the outset.

Consideration of the following recommendations is required to progress the creation, adaptation, and adoption of open educational resources:

(1) Establishing a clear strategic direction and supporting infrastructure regarding the development of OER textbooks, ancillary resources, as well as supporting open education institutionally. This could be envisaged as a specific role or team that engages with:

- awareness raising workshops;

- ensuring compliance with Creative Commons licenses and attribution;

- establishing an open education working group at the home institution to progress the discussion;

- spearheading the development of an open education framework that has University wide endorsement and is embedded in policy;

- addressing the barriers to adoption and adaptation for academic staff.

(2) Consideration of tailored grant schemes to incentivise the creation, adaptation, adoption and review of OER. For example: offering tiered categories of grant funding or time release. 
[Table 1: Example of a grant scheme with tiered funding.]

\begin{tabular}{|l|l|l|l|}
\hline Level/Tier & Who & Condition & $\begin{array}{l}\text { Grant funding } \\
\text { or time release } \\
\text { \$ADD }\end{array}$ \\
\hline 1 & $\begin{array}{l}\text { Higher degree students to } \\
\text { review OER resources }\end{array}$ & $\begin{array}{l}\text { Review the quality and } \\
\text { viability via controlled } \\
\text { rubric }\end{array}$ & $\$ 200-\$ 500$ \\
\hline 3 & Academic/Teaching staff & $\begin{array}{l}\text { Adopt an OER textbook } \\
\text { and report how teaching } \\
\text { practice has changed }\end{array}$ & $\$ 500$ \\
\hline 4 & Academic/Teaching staff & $\begin{array}{l}\text { Adapt and customise an } \\
\text { existing OER textbook }\end{array}$ & $\$ 1,000-\$ 2000$ \\
\hline 5 & $\begin{array}{l}\text { Higher Degree students/ } \\
\text { Academic/Teaching staff }\end{array}$ & $\begin{array}{l}\text { Creation of ancillary } \\
\text { material for adopted } \\
\text { OER textbooks }\end{array}$ & $\$ 1,000-\$ 2000$ \\
\hline Co-creation with students/ & $\begin{array}{l}\text { Creation and } \\
\text { development of new } \\
\text { OER textbook }\end{array}$ & $\$ 2,000-\$ 5,000$ \\
\hline
\end{tabular}

(3) An Australia wide shared subscription to an authoring platform like

PressbooksEDU to create and adapt open works and to provide a standardised design and professional appearance, supported and endorsed by peak bodies such as CAUL or ALIA.

(4) Developing OER champions within the Library and/or in colleges/faculty.

(5) Leveraging student advocates. Establishing campaigns at home institutions to ensure the student voice is heard.

(6) Obtaining funding from bodies such as LATN, CAUL, Universities Australia, to support wider initiatives on OER awareness, creation and adaptation.

(7) Developing partnerships and collaborations beyond academia.

For example: partnering with TAFE libraries or industry to create/adopt/adapt OER. 
(8) Influencing policy change at home institutions that incentivises and recognises the development of open educational resources as evidence towards promotion for academic staff.

\section{Development of the Open Educational Resources Librarians Network (OERLN) and Open Textbook Initiative}

A local group at RMIT University Library was formed to establish an OER portal which incorporated representation from other ATN Libraries. Beginning its existence as the Open Educational Resources Librarians Network Textbook Initiative, and launched in late 2018, the site aimed to broadly discuss the open textbook and other OER initiatives within ATN libraries. It was soon apparent there needed to be harmonisation between the broad parameters of the OER Librarians Network (OERLN) and the discourse surrounding open textbooks. Therefore, it was decided that the site would be rebadged the Open Textbook Initiative as this moniker provided a clearer focus. All university libraries would continue to access and contribute to the site and responsibility for hosting the site resided with RMIT Library. The site continues to serve as a focal point for the OERLN but now has an explicit lens on the open textbook.

The Open Textbook Initiative provides a platform to find resources, capture and demonstrate student savings made from OER adoption, emphasise curated OER from featured disciplines, and establishes the 'textbook heroes' moniker that highlights textbook adoptions and/or changes to teaching practice as a result of their use by academic staff.

The Open Textbook Initiative is a publicly accessible site and treated as a shared resource for all University libraries, hosted at RMIT, with links to OERLN representatives from other ATN libraries. Representatives and colleagues from other institutions are encouraged to contribute to the portal in some capacity, either via shared 
Creative Commons resources, or by highlighting the contribution of an academic staff member who has saved students' money or altered their teaching practice to incorporate open educational resources. (see appendix for image screenshots)

The Open Textbook Initiative site strongly encourages the sharing of resources. i.e. infographics, images, powerpoint slides etc so that others can build upon, adapt and re-share. The portal aims to act as an entry point to customised local toolkits, guides, webinars and promotional material associated with open educational resources and open advocacy. To this end, RMIT University has produced several resources with the purpose of sharing and allowing adaptation. They have been badged with a Creative Commons license with the aim of encouraging other University representatives to contribute shareable content as well.

\section{Success of the Open Textbook Initiative}

A key deliverable of the fellowship for RMIT University Library was a webinar presentation on the establishment of the LATN Open Educational Resources Librarians Network and the launch of the Open Textbook Initiative. The webinar was delivered to over ninety participants, recorded, and shared on the Open Textbook Initiative website. The webinar discussed the learning from BCcampus and how the Open Textbook Initiative began. This was followed in 2019 with a subsequent webinar outlining the beginnings of an Open Educational Practices' Framework at RMIT University. The drivers associated with the development of an Open Educational Practices Framework stem from key strategic factors at RMIT University: student retention, engagement and success. It is about broadening the scope of OER from adoption to the way in which teaching practice is transformed to enhance student engagement and success. Additionally, the progression to an Open Educational Practices' Framework should 
highlight greater flexibility associated with OER to academic staff, such as, customisation, remixing and co-creation with students.

In late 2018, La Trobe University and RMIT University Libraries collectively delivered an Open Textbook Forum over two days. This event engaged open textbook authors from La Trobe University, discussed the development of La Trobe University Library eBureau (La Trobe University, 2017) and the development of open textbooks from inception to delivery. RMIT University Library hosted two international speakers, Rajiv Jhangiani from Kwantlen Polytechnic University, and Nicole Allen from the Scholarly Publishing and Academic Resources Coalition (SPARC) who are renowned OER experts. They engaged participants in discussions on Canada's first Zed Cred program, how to reduce student costs, expand access to open content, and participate in open pedagogy.

An integral part of understanding OER is the ability to advocate and create awareness. To demonstrate and mitigate the barriers associated with OER adoption in Australia, the Open Textbook Initiative provides a navigable site with links to useful resources and platforms, curated subject lists of OER textbooks, and an automated capture of student savings as academic staff self-report OER textbook adoptions. In addition, RMIT Library staff have adopted the language of open practice when in conversation with academic staff, delivered awareness sessions and have been deeply embedded with college blended learning initiatives where OER textbooks are discussed as valid alternatives to commercial textbooks. (see: Appendix)

In 2018, a project team was established at RMIT University Library ensuring that a Library voice advocates for OER adoption. This project team was tasked with custodianship of the Open Textbook Initiative site and has delivered multiple group and individual sessions on finding open educational resources, understanding Creative 
Commons and copyright material to RMIT staff and students. They have also engaged with two RMIT authors on how their original content could be delivered openly.

The project team also produced and hosted a newsletter entitled 'OER Round up' on a quarterly basis that aimed to bring together and share open activities in Australia and New Zealand. The first issue was produced by RMIT University Library and the production of each issue shared amongst the network via the portal. In more recent times, the newsletter has ceased, and contributions have extended to the Open Educational Practices Special Interest Group (OEPSIG) newsletter.

In mid-2019, a decision was made to create a closer relationship with the Open Educational Practices Special Interest Group (OEPSIG). The intent of this collaboration was to broaden the discussion from the open textbook as a resource to open practice where open resources are used in ways that contribute to student engagement and learning. There were strong synergies between the Open Textbook Initiative and the OEPSIG and it seemed counterintuitive to progress as separate entities when both groups had a similar philosophy and outlook. Consequently, members of the Open Educational Resources Librarians Network were invited to join the OEPSIG and contribute to the discussion via this platform.

\section{Further OER Research in Australia}

In order to make change in Australia, fiscal support and strategic government policy will be important. Further support and planning will be required from peak bodies such as CAUL and ALIA to nationalise this work and progress it further. If government policy is enacted, educational institutions will begin to establish a benchmark for operational projects that focus on OER awareness and adoption as well as open education. The OpenEdOz National Roadmap clearly articulated the individual 
strategies that could contribute to national action and the organisations that have a role to play in their implementation (OpenEdOz National Roadmap, 2016). Threads of collaborative action are slowly bubbling to the surface. The CAUL Digital Dexterity Framework (2019) has facilitated groups of Librarians in Australia and New Zealand to build digital skills and establish a resource sharing repository that allows for reuse and adaptation under creative commons. The OERu, an international network of educational institutions who aim to provide formal qualifications to learning for all students worldwide based on OER courses are engaging with multiple Australian and New Zealand partners. They are continually increasing institutional membership, providing clearer pathways for international credit transfer through OER courses and increasing the number of student course registrations.

Government policy in Australia is focused on open access research and still lags the rest of the world in supporting and promulgating open teaching and learning resources (Office for Learning and Teaching, 2016). An example of OER policy and state legislative support comes from the Scholarly Publishing and Academic Resources Coalition (SPARC). This body is committed to ensuring the Affordable College Textbook Act is passed (U.S. 116 ${ }^{\text {th }}$ Congress, 2019-2020). If this bill is ratified it will reduce the cost of textbooks at US colleges and universities by expanding the use of open textbooks throughout the USA. Bossu and Stagg (2018) highlight the paradox that exists in Australia between the OER movement and government policy; OER clearly has its identity entrenched in social equality, but in contrast, government policy favours a university education that is aligned with job readiness and often alludes to education as a commodity. For OER policies to succeed more broadly in Australia, this distinction needs to be fully understood and addressed. 
A growing group of key OER advocates is building in Australia, emerging from university libraries, eLearning teams, publishers, and student access and equity areas. One example in Australia is Sydney University Press. They have created their first OER textbook entitled Australian Politics and Policy, which was launched late 2019. It is completely customisable and has undergone rigorous peer review. Further research is required to investigate the value, strengths and limitations of this textbook. The results would improve future iterations and contribute to the broader scholarship on the creation and adoption of open educational resources in Australia.

Another OER creator is La Trobe University Library. They assist academic staff to produce original content with an open license and ensure the resulting work is used within a course of study. This is a mandatory stipulation before creation. In a recent study of the efficacy of open textbooks at La Trobe University, it was found that human physiology students preferred e-textbooks over traditional hard copy textbooks, suggesting cost sensitivities for the preference. Additionally, immediate access to the OER textbook also aided students in expediting their assessment tasks. Interestingly, the text has had wider adoption and is being used across the world at other institutions giving the authors significant global reach and impact. (Julien, B. L., Lexis, L., Salisbury, F., Russell, K., \& Loch, B., 2018).

These examples demonstrate how OER textbooks can address student affordability. The mere selection and use of an OER textbook within a course of study can reduce costs to education and increase the chances of success for learners who come from a low socio-economic background and are marginalised in education. Lambert, (2018) refers to this act as redistributive justice and is recognised as one of the three principles of social justice applied to open education. 
The other two social justice principles are recognitive justice and representational justice which are emerging areas within open education. Recognitive justice is the inclusion of images and case studies that reflect diverse points of views, and representational justice allows the voices of marginalised groups to be represented in textbooks and the open curriculum (Lambert, 2018). This is a vital area of research bringing to light the importance of how OER offers the flexibility to allow academic staff to include new and diverse points of view in their teaching practice. It also affords teachers the opportunity to experiment with open assessment where students are given agency to co-create and publish content openly, ultimately creating deeper connections to learning based on unique stories and points of view.

There is more research required in recognitive and representational justice applied to open education. Researchers from Deakin University have been funded to look at the potential of open textbooks to act as social justice in Australia. This research seeks to remedy injustice across the three dimensions: economic, identity and representation. They are interested in saving student's money with open textbooks, and in addition, to ensure diverse students can recognise themselves inside their textbooks. RMIT University Library will be engaged with this research through conversations with the researchers and facilitating access to academic staff who have adopted OER textbooks at RMIT. (Deakin University, 2020).

\section{Conclusion}

OER discussion and policy is only emerging at an institutional level. The discussion is fragmented and piecemeal. The RMIT Library example has specifically focused on the open textbook and aimed to position university libraries as key advocates in the delivery of awareness and adoption of open educational resources. The Open Textbook Initiative 
website remains the focal point for the OERLN members to connect, disseminate information and create awareness but acknowledges that the discussion is broader than open textbooks and has aimed to broaden the discussion by the collaborative partnership with the Open Educational Practices Special Interest Group and Deakin University researchers.

This paper has also identified that acknowledging and adopting open educational resources is the first stage towards open practice and that widening the discussion beyond the resource itself to how it can be applied within an educational context is the real story. Consideration needs to be given to how libraries can provide a robust infrastructure to support academic staff in the creation and adaptation of OER, and sustainable models must be adopted to have the desired impacts. 


\section{References}

Australia. Office for Learning and Teaching, (issuing body.) \& Australia. Department of Education and Training, (sponsoring body.) (2016). Students, universities and open education : final report 2016. Australian Government, Department of Education and Training, Canberra, ACT

Australian Technology Network. (n.d.). About Section. https://www.atn.edu.au/aboutus/

Barbour, V., \& Borchert, M. (2020). Open Science: after the COVID-19 pandemic there can be no return to closed working. Australian Academy of Science. https://www.science.org.au/curious/policy-features/open-science-after-covid-19pandemic-there-can-be-no-return-closed-working

BCcampus. (n.d.). Open Education Advocacy: Open Educational Resources. https://bccampus.ca/open-education-advocacy/

BCcampus. (n.d.). Our Mandate. https://bccampus.ca/about-us/our mandate/

BCcampus. (n.d.). What is Open Pedagogy. https://open.bccampus.ca/what-is-openeducation/what-is-open-pedagogy/

Bliss, T. J., \& Smith, M. (2017). A brief history of open educational resources. In R. S. Jhangiani \& R. Biswas-Diener (Eds.), Open: The philosophy and practices that are revolutionizing education and science (pp. 9-27). Ubiquity Press.

Bliss, TJ, Hilton III, John, Wiley, David, \& Thanos, Kim. (2013). The cost and quality of online open textbooks: Perceptions of community college faculty and students. First Monday, 18(1). https://doi.org/10.5210/fm.v18i1.3972

Bossu, C., Brown, M., \& Bull, D. (2012, November 25-28). Do open educational resources represent additional challenges or advantages to the current climate of change in the Australian higher education sector? ASCILITE 2012: 29th Annual Conference of the Australasian Society for Computers in Learning in Tertiary Education: Future Challenges, Sustainable Futures, Wellington, New Zealand.

Bossu, Carina, Bull, David, \& Brown, Mark. (2012). Opening up Down Under: the role of open educational resources in promoting social inclusion in Australia. Distance Education, 33(2), 151-164. https://doi.org/10.1080/01587919.2012.692050 
Bossu, C., Bull, D., \& Brown, M. (2012, September 19-21). The open education movement in Australia: The need for political leadership. Regional Symposium on Open Educational Resources (OER 2012): An Asian Perspective on Policy and Practices, Penang, Malaysia.

Bossu, C., Bull, D., \& Brown, M. (2015). Enabling open education: A feasibility protocol for Australian higher education. In C. Bonk, M. Lee, T. Reeves, \& T. Reynolds (Eds.), MOOCs and open education around the world. Routledge.

Bossu, C., \& Stagg, A. (2018). The potential role of Open Educational Practice policy in transforming Australian higher education. Open Praxis, 10(2), 145-157.

Bossu, C., Ward, L., Wills, S., Alexander, S., Sadler, D., Kandlbinder, P., Brown, N., Chelliah, J., Klapdor, K., \& Uys, P. (2016, November 28-30). A national strategy to promote Open Educational Practices in higher education in Australia: Show Me The Learning. (ASCILITE, 2016) Adelaide, South Australia. https://2016conference.ascilite.org/wpcontent/uploads/ascilite2016_bossu_concise.pdf

Braddlee, D., \& VanScoy, A. (2019). Bridging the chasm: Faculty support roles for academic librarians in the adoption of open educational resources. College $\&$ Research Libraries, 80(4), 426-449. https://doi.org/10.5860/crl.80.4.426

British Columbia Federation of Students (BCFS). (2019). Open Textbooks Now. http://www.wearebcstudents.ca/our-campaigns/textbooks

Browne, T., Holding, R., Howell, A., Rodway-Dyer. S. (2010). The challenges of OER to Academic Practice. Journal of Interactive Media in Education : JiME, 2010(1). https://doi.org/10.5334/2010-3

Bull, D., Bossu, C., \& Brown, M. (2011, October 2-5). Gathering the evidence: The use, adoption and development of open educational resources in Australia. ICDE 2011: Expanding Horizons: New Approaches to Open and Distance Learning, Denpasar, Indonesia.

Burgess, M. (2017). The BC open textbook project. In R. S. Jhangiani \& R. BiswasDiener (Eds.), Open: The philosophy and practices that are revolutionizing education and science (pp. 227-236). Ubiquity Press.

CAUL. (2019). Digital Dexterity Framework. https://www.caul.edu.au/digital-dexterityframework 
Charles Darwin University, (n.d.) CDU Open Book Publishing: Pressbooks Publishing Platform. https://cduebooks.pressbooks.pub/

Colvard, N., Watson, C. E., \& Park, H. (2018). The impact of open educational resources on various student success metrics. International Journal of Teaching and Learning in Higher Education, 30(2), 262-276.

Creative Commons. (2011). History "Some Rights Reserved": Building a Layer of Reasonable Copyright. https://wiki.creativecommons.org/wiki/history

Deakin University. (2020). Australian Open Textbooks Project. http://australianopentextbooks.edu.au/

Jhangiani, R. (2014, July 28). The great psychology testbank sprint. $\mathrm{http}: / /$ thatpsychprof.com/the-great-psychology-testbank-sprint/

Julien, B. L., Lexis, L., Salisbury, F., Russell, K., \& Loch, B. (2018). Human physiology students' perceptions of etextbooks: towards open access as an alternative to traditional textbooks. International Journal of Innovation in Science and Mathematics Education (formerly CAL-laborate International), 26(7).

https://openjournals.library.sydney.edu.au/index.php/CAL/article/download/126 $50 / 11844$

La Trobe University. (2017). eBureau. https://library.latrobe.edu.au/ebureau/

Lambert, S. R. (2018). Changing our (dis)course: A distinctive social justice aligned definition of open education. Journal of Learning for Development, 5(3).

Library Journal. (2019). Textbook Affordability Survey Report.

https://s3.amazonaws.com/WebVault/research/Textbook\%20Affordability\%20S urvey\%20Report-final.pdf

Matt. (2003, June 23). Creative commons welcomes David Wiley as educational use license project lead.

https://creativecommons.org/2003/06/23/creativecommonswelcomesdavidwiley aseducationaluselicenseprojectlead/

MERLOT. (n.d.). Who Are We.

http://info.merlot.org/merlothelp/topic.htm\#t=Who_We_Are.htm

OERu. (n.d.). https://oeru.org/

OpenEdOz. (2016). OpenEdOz National Roadmap 2016

https://openedoz.org/wp-content/uploads/2017/06/OpenEdOz_Roadmap.pdf 
Open Educational Practices Special Interest Group (OEPSIG) (n.d.).

https://oepoz.wordpress.com/

Open Textbook Initiative. (2019). https://emedia.rmit.edu.au/oer/

Partridge, H., Stagg, A., \& Power, E. (2016, November 28-30). Developing low-barrier courses using open textbooks: A University of Southern Queensland case study. 33rd International Conference of Innovation, Practice and Research in the Use of Educational Technologies in Tertiary Education: Show Me the Learning (ASCILITE 2016), Adelaide, South Australia.

QUT. (n.d.) QUT eBooks: Queensland University of Technology’s Open Textbook Platform. https://qut.pressbooks.pub/

Rekhari, Suneeti, Curran, Lisa, Paul, Anselm, \& Porcaro, Pauline. (2020). Enabling Holistic Curriculum Transformation by Using 'Thoughtfully' Designed Blended Activities and Resources. In Tertiary Education in a Time of Change (pp. 113124). Springer Singapore. https://doi.org/10.1007/978-981-15-5883-2_9

Scholarly Publishing and Academic Resources Coalition (SPARC). (2017). OER Mythbusting. https://sparcopen.org/our-work/oer-mythbusting/

Smith, B., \& Lee, L. (2017). Librarians and OER: Cultivating a community of practice to be more effective advocates. Journal of Library \& Information Services in Distance Learning, 11(1-2), 106-122. https://doi.org/10.1080/1533290X.2016.1226592

Stagg, A., Nguyen, L., Bossu, C., Partridge, H., Funk, J., \& Judith, K. (2018). Open educational practices in Australia: A first-phase national audit of higher education. International Review of Research in Open and Distributed Learning, 19(3), 172-201. https://doi.org/10.19173/irrodl.v19i3.3441

Universities Australia. (2018). 2017 Universities Australia Student Finances Survey. https://www.universitiesaustralia.edu.au/wp-content/uploads/2019/06/1807132017-UA-Student-Finance-Survey-Report.pdf

University of British Columbia, (n.d.) Tenure and Faculty Appointments https://hr.ubc.ca/career-development/tenure-and-faculty-appointments

University of Southern Queensland, (n.d.) Open Access Textbooks https://usq.pressbooks.pub/

US 116 ${ }^{\text {th }}$ Congress. (2019-2020). Affordable College Textbook Act. H.R. 2107. https://www.congress.gov/bill/116th-congress/house-bill/2107 
Vitez, K. (2018). Open 101. An Action Plan for Affordable Textbooks.

https://uspirg.org/sites/pirg/files/reports/OPEN\%20101\%20final\%20\%5BKV.01 $.25 .18 \% 5 \mathrm{D} . \mathrm{pdf}$

Walz, A. (2017). A library viewpoint: Exploring open educational practices. In R. S. Jhangiani \& R. Biswas-Diener (Eds.), Open: The philosophy and practices that are revolutionizing education and science (pp. 147-162). Ubiquity Press. 


\section{Appendix:}

Image 1: Open Textbook Initiative - Front page https://emedia.rmit.edu.au/oer/

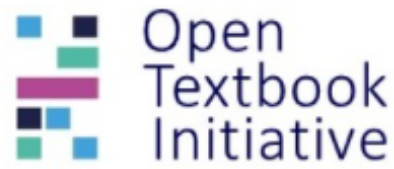

Home About - Academic staff - Librarians - Support * News - $Q$

\section{FIND}

Search the collection for peer reviewed open textbooks.

Get started with these OER textbook suggestions for your subject.

Student Savings: $\$ 255,147$

\section{Featured Textbooks}
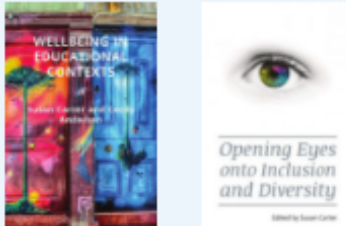

Wellbeing in Educational Contexts by Susan Carter and Cecily Andersen

Opening Eyes onto Inclusion and Diversity

by Susan Carter, Professor Lindy-Anne Abawi, Professor Jill Lawrence, Associate Professor Charlotte Brownlow, Renee Desmarchelier, Melissa Fanshawe, Kathryn Gilbey, Michelle Turner, and Jillian Guy

Read the abstracts of these featured USQ

\section{ADOPT}

Consider adopting a textbook for your course/subject/unit. Follow some easy steps to adopt open textbooks for your teaching

Let us know if you have adopted an open textbook.

\section{ADAPT}

Take advantage of the open textbook Creative Commons license and customize an open textbook to fit your specific needs.

Contact your representative to discuss options for adaptation.

\section{Textbook Adoptions: 18 Participating Institutions: 2 Adoption details}

\section{Open Educational \\ Practice Special Interest Group (OEP-SIG)}

The Open Educational Practice Special Interest Group (OEP-SIG) provides practitioners, researchers and advocates a platform for collaboration, support and development at both the individual and institutional levels and create a strong community of practice and representation for OEP in Australasia.

Join the OEP-SIG to keep up to date with new developments.

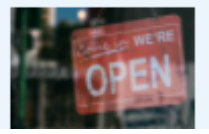

OEP-SIG Sign-up form Monthly Digest Meetinas \& Events y \#oer

$$
\text { Gerald Uhr } 30 \mathrm{~m}
$$

\#Trump, volle Hallen, Kilometerlange Autokorsos

\#Biden mit ein paar verstreuten Anhängern in leeren Autokinos, er etwas debil

\#ŌR, \#Lanz \#Jounalisten in Deutschland das wird ein ganz knappes Rennen

$$
\leftrightarrow \text { t } 11 \text { Twitter }
$$

Don Gorges 1h

@realDonaldTrump Another of

(Q) realDonaldTrump's myriad shameless manipulations of reality

like no one has ever seen before 


\section{Image 2: Open Textbook Initiative - Textbook heroes}

\section{Julian Lee}

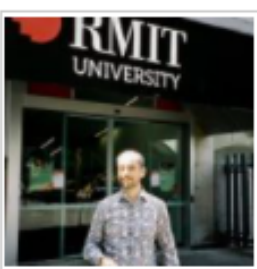

Dr Julian CH Lee

School of Global, Urban and Social Studies

julian.lee@rmit.edu.a.

Course: SOUC1011

Saved students: $\$ 4,225$ in 2019

By prescribing an OER Textbook: Monsters of Modernity: Global icons for our critical conditions

(Student savings based on this commercial work: Globalization East and West)

Julian Lee, by Romy Martini.

Comments from Dr Julian CH Lee:

What is the main challenge faced by your students? How do they learn and what do they find difficult?

Global Processes is about globalisation, and many concepts about globalisation are abstract and therefore sometimes difficult to grasp. But even commonplace concepts such as neoliberalism have proven difficult to teach, because neolibera/ thinking is part and parcel of life today, and it is impossible for people to imagine the world differently. Finding ways to discuss that which is abstract or ubiquitous has sometimes been a challenge

What change have you made to respond to this challenge?

In some of the weeks of our course, we used Monsters of Modernity. This book of ours was our attempt to enable students to grasp concepts and ideas that were challenging in diverse ways by using familiar monsters as vehicles and symbols of wider more general phenomena. So, with respect to neoliberalism, Pokémon (which are 'pocket monsters') embody the highly acquisitive and individualistic nature of contemporary society. We spent time in class talking about Pokémon and Pokémon Go, which was cool fun.

What has the impact of the change been (for students and you/the teaching team)?

Historically, the week on neoliberalism was the hardest to teach (although /m sure many would be surprised to hear this). This year, we all fe/t that the students 'got it' much more easily

Another unexpected impact in using an open access text is that, in addition to the obvious and much appreciated financial ease it confers on students, it also frees course coordinators from the obligation of getting the most value out of a text. I could, if / choose, not use all the book without feeling that the unused chapters have been a waste of money for students.

What next?

I'd like to become an open access ninja and really get to understand the whole scene better, as well as spread the word amongst colleagues. It would also be important to ensure that we give the same or more esteem to colleagues who publish with open access publishers because the obligation to chase prestige could cause many to choose publishers with renown despite the impact on readers, including students and those from places where the cost of an academic book is not just expensive, but prohibitive, given their purchasing power parity. 
Image 3: Open Textbook Initiative - OER textbook adoption details.

\begin{tabular}{|c|c|c|c|c|c|c|c|c|}
\hline Date & Name & Course code & Course name & Institution & OER adopted & $\begin{array}{l}\text { Number of } \\
\text { students }\end{array}$ & Former textbook: & $\begin{array}{l}\text { Cost of new } \\
\text { commercial } \\
\text { copy: }\end{array}$ \\
\hline $30 / 07 / 2020$ & $\begin{array}{l}\text { Lilibeth } \\
\text { Jandug- } \\
\text { Montera }\end{array}$ & АССТ2160 & $\begin{array}{l}\text { Cost Analysis } \\
\text { and } \\
\text { Applications }\end{array}$ & RMIT & Managerial Accounting & 36 & Managerial Accounting & 231.89 \\
\hline $01 / 07 / 2020$ & $\begin{array}{l}\text { Michaela } \\
\text { Jackson }\end{array}$ & COMM2685 & $\begin{array}{l}\text { Communicating } \\
\text { the } \\
\text { Organisation }\end{array}$ & RMIT & $\begin{array}{l}\text { Organizational Communication - } \\
\text { Theory, Research, and Practice }\end{array}$ & 70 & Conrad \& Poole (2012) & 104 \\
\hline $14 / 01 / 2020$ & Amy Griffin & $\begin{array}{l}\text { GEOM } 2157 \\
\text { GEOM } 2159\end{array}$ & $\begin{array}{l}\text { Geospatial } \\
\text { Programming }\end{array}$ & RMIT & Think Python, 2nd Edition & 30 & none & 40 \\
\hline $13 / 01 / 2020$ & $\begin{array}{l}\text { Nevena } \\
\text { Todorova }\end{array}$ & OENG1208 & $\begin{array}{l}\text { Engineering } \\
\text { Science }\end{array}$ & RMIT & Open Stax Chemistry $2 \mathrm{e}$ & 340 & $\begin{array}{l}\text { Chemistry: The } \\
\text { Molecular Nature of } \\
\text { Matter and Change }\end{array}$ & 210 \\
\hline $13 / 01 / 2020$ & Fabio Zambetta & $\operatorname{cosc} 1284$ & $\begin{array}{l}\text { Programming } \\
\text { Techniques }\end{array}$ & RMIT & $\begin{array}{l}\text { Think Java: How To Think Like } \\
\text { a Computer Scientist }\end{array}$ & 320 & $\begin{array}{l}\text { Intro to Java } \\
\text { Programming }\end{array}$ & 96 \\
\hline $22 / 07 / 2019$ & Trevor Stone & $\operatorname{cosc} 2511$ & $\begin{array}{l}\text { Introduction to } \\
\text { Programming }\end{array}$ & RMIT & $\begin{array}{l}\text { Think Java: How to think like a } \\
\underline{\text { Computer Scientist }}\end{array}$ & 199 & $\begin{array}{l}\text { Java How to Program - } \\
\text { Late Objects, Global } \\
\text { Edition, 10th Edition }\end{array}$ & 107.06 \\
\hline $30 / 04 / 2019$ & Claire Ovaska & WS2006 & $\begin{array}{l}\text { International } \\
\text { Exchange }\end{array}$ & $\begin{array}{l}\text { James Cook } \\
\text { University }\end{array}$ & $\begin{array}{l}\text { Intercultural Learning: Critical } \\
\text { preparation for international } \\
\text { student travel }\end{array}$ & 37 & no textbook in past & 0 \\
\hline $22 / 02 / 2019$ & James Harland & $\operatorname{cosc} 2627$ & $\begin{array}{l}\text { Discrete } \\
\text { Structures in } \\
\text { Computing }\end{array}$ & RMIT & The Book of Proof - CC-BY-ND & 310 & $\begin{array}{l}\text { Mathematical Proofs: A } \\
\text { Transition to Advanced } \\
\text { Mathematics }\end{array}$ & 219.95 \\
\hline $07 / 08 / 2018$ & James Harland & $\operatorname{cosc} 2627$ & $\begin{array}{l}\text { Discrete } \\
\text { Structures in } \\
\text { Computing }\end{array}$ & RMIT & The Book of Proof - CC-BY-ND & 317 & $\begin{array}{l}\text { Mathematical Proofs: A } \\
\text { Transition to Advanced } \\
\text { Mathematics }\end{array}$ & 219.95 \\
\hline
\end{tabular}

